\title{
The Authority of Prosecutors in Supervision of Every Investigation of Police and Civil Servant Investigators
}

\author{
Novriadi Andra ${ }^{1}$, Megawati Barthos ${ }^{2}$ \\ Student Program Doctor of Law Borobudur University, Jakarta, Indonesia ${ }^{1,2}$
}

\{Andra.noviandri@gmail.com¹, megawati_barthos@borobudur.ac.id²\}

\begin{abstract}
So far, there are no clear rules for the practice of investigations by police investigators and civil servant investigator (PPNS) due to the loss of prosecutors' function in supervising and completing police and PPNS investigations. So it is necessary to have the authority for the prosecutors to provide supervision of investigators of the National Police and PPNS. The approach used in this paper is a normative juridical approach using secondary data as an additional source, in the form of various laws and regulations and other document references related to assessment, research, and the legislation process. This study concludes that public prosecutors / public prosecutors' involvement in Police and civil servant investigators' supervision increases the prosecution's success in court and provides legal standing for prosecution arrangements by prosecutors / public prosecutors in court.
\end{abstract}

Keywords: Supervision; Investigation; Persecution;

\section{Introduction}

Police investigators have the authority, as mentioned in Article 7 paragraph (1), KUHAP, while for PPNS, its jurisdiction following the law that becomes the basis of their respective directions. As in Article 6 paragraph (1), KUHAP mentions two officials domiciled as Investigators, namely Police Investigators and Civil Servant Investigators (PPNS).

Coordination is a form of working relationship between police investigators and PPNS in investigating certain crimes that become the legal basis under functional relationships' joints. At the same time, supervision is reviewing and briefing on the implementation of investigations by PPNS to ensure that all activities carried out under the legislation. The performance of coordination and control by the Police Investigators on PPNS is carried out based on Independence, togetherness and legality.

The criminal investigation process is one of the subsystems in the criminal justice system in Indonesia. It has a significant and strategic position because it becomes the entrance and the beginning of the law enforcement process. The investigation process is mandated by KUHAP to the Police Investigators and PPNS, although in its development appears other Investigators such as KPK Investigators, Prosecutors Investigators, Navy Officer Investigators. The authority of police investigators regulation in KUHAP (Article 7 paragraph (1), while the power of PPNS is regulated under the law that becomes the basis of their respective laws and 
in the implementation of their duties under the coordination and supervision of police investigators (KUHAP Article 7 paragraph (2).

The mechanism of implementation of coordination and supervision conducted by the Police Investigators against PPNS in the investigation process has been regulation in Law No. 8 of 1981 concerning KUHAP and Law No. 2 of 2002 concerning the State Police of the Republic of Indonesia, as well as other Laws and Regulations. The coordination and supervision of police investigators to PPNS, in addition to the mandate of the law, is also expected to cooperate in synergy and cohesion in the process of law enforcement carried out by police investigators and PPNS, so that it is an expectation that the law enforcement process can run optimally.

\section{Methods}

The approach used in this paper is a normative juridical approach using secondary data as an additional source, in the form of various laws and regulations and other document references related to assessment, research, and the legislation process. We use existing data in the library and a functional system in these books.

\section{Discussion}

\subsection{The Supervisory Role of the Prosecutor's Office}

The role of prosecutorial supervision as in the main task of the prosecutor is to carry out planning and control of the internal performance and finances of all elements of the Prosecutor's Office both at the High Prosecutor's Office, the State Prosecutor's Office and the Branch of the State Prosecutor's Office in the relevant jurisdiction of the High Prosecutor's Office, as well as carrying out supervision for a specific purpose on the assignment of the Chief Prosecutor following the provisions of the legislation.

Conduct pre-prosecution, examination, addition, prosecution, execution of judges and court decisions, supervision of conditional release decisions and other legal actions in general criminal cases based on legislation and discretion by the Attorney General.

The Prosecutor's Commission is a non-structural government institution in carrying out its duties, functions, authorities and roles independently, free from the influence of any power. The Prosecutor's Commission is under and responsible to the President. The task carried out by the prosecutorial commission concerns 3 (three) things, namely: supervision, monitoring and assessment. The role played by the prosecutorial commission is not only to the performance or behaviour of prosecutors and prosecutorial employees only but also concerns the condition of the organization, completeness and human resources. Thus, the presence of this prosecutorial commission should welcome by the public in Indonesia. With this commission, it is expected that law enforcement officials' performance, especially prosecutors, will be even better. The role of the prosecutorial commission, in essence, requires good coordination from the internal supervisory apparatus of the prosecutor, which is the form of coordination that is the prosecutorial commission after giving a report or recommendation to the Attorney General and the Attorney General gives it back to the internal supervisor of the prosecutor (Jamwas) for further processing. The prosecutorial commission will always look at the extent of the progress of examining the report received by the prosecutor's internal 
supervisory apparatus. Then within 3 (three) months, if the prosecutor's commission's message is not progressed or not followed up by the prosecutor's internal supervisor, the prosecutorial commission can take over the examination.

Prosecutors also serve as institutions that have a role and duty in overseeing prosecutors' performance, especially prosecutors or prosecutors. The prosecutor's commission has various constraints, and the prosecutorial commission has only one secretariat located in the nation's capital, then the limitations of members who only number 9 (nine) people. It will significantly affect the prosecutorial commission's performance and role as a supervisory agency because the supervised institutions or institutions are located in all provinces in Indonesia.

\subsection{Supervision of the Prosecutor's Office of Police Investigators and Civil Servant Investigators (PPNS)}

As we know that KUHAP has clearly and decisively set the authority of police investigators (plus auxiliary investigators), civil servant investigators (PPNS) and public prosecutors in the investigation stage so that each agency has been carrying out its duties and functions, of course, with all the twists and turns and obstacles (both internal and external). But as time goes on and the development of the times, the implementation of these tasks and functions, of course, always experience the dynamics of problems that sometimes are not or have not been anticipated by the law, let alone the law is only the work of man that will never be perfect, only naïve human beings who call law is the excellent work of the son of man.

Problems that arise and are not anticipated/accommodated by the law, by its implementers, will seek solutions on an initiative basis. Over time, it will become a customary practice that is misguided or even settles, and someday the sediment will increasingly cause decay in the system. It, of course, should not be allowed to happen continuously before the procedure is wholly decomposed from the inside, which could lead to system failure. Therefore, if any subsystem indication to have been running unhealthily, it should be repaired or refurbished.

In general, if seen in the process of conducting investigations that have been running so far seems as if it always goes smoothly without being hampered by significant problems, this is if viewed from the pattern of working relationship between the Public Prosecutor and the Police Investigator in the framework of investigating public criminal cases. But if we look more deeply, it will be found problems that the author thinks are disturbing the author's visionary view in the perspective of the development of criminal law and the handling and countermeasures of criminality in the future.

The central issue that can be identified is the existence of Civil Servant Investigators (PPNS) subordinated to the Police Investigators; this has been a long-running issue that has had fatal implications for the quality of the existence of PPNS and administrative penal law enforcement. This central issue has a domino effect on the next problem, namely by "falling asleep" PPNS. Then law enforcement for certain criminal violations of administrative penal law becomes resting on police investigators' shoulders. Whereas the trend of illegal law development in Indonesia is growing with various Administrative Penal Law, studying criminal law in its law certainly requires a lot of time and mind. Of course, it takes intellectual skills from investigators who are Bachelor of Law and Bachelor of Law investigators, whereas the number of investigators in police agencies is limited. This situation further makes the Police increase the number of auxiliary investigators (rank of petty officer), which is in terms of ability, legal knowledge and intellectuality can not be guaranteed. This rank is undoubtedly not suitable if reviewed from the balance of Public Prosecutor and Judge's position. That is why there are often inadequate and undirected investigations that result in frequent back and 
forth of case files between JPU and Investigators / Investigators Permhelp. Do not investigate certain criminal cases; for general criminal cases are still very often encountered similar problems.

A brief description of the integrated criminal justice system can be seen, the success or not of the function of the court examination process conducted by JPU and Hakim to declare the accused guilty and subsequently criminalize it, depending on the results of the investigation of the investigator. Blurred, undirectional and deliberate case files about suspected criminal events are often found in judicial practice. As a result, the proceedings often have difficulty proving the defendant's guilt. Furthermore, the blurred case file is further away from the possibility of blaming and punishing the accused because the evidence submitted by the investigator does not meet the minimum evidentiary limit outlined by Article 183 KUHAP because: In general, investigators are more likely to collect and present evidence quantitatively, not qualitatively, and sometimes of the many evidence tools submitted, none of which are eligible formal and materiel, which results in the proposed evidence tool does not reach the minimum limit of proof, so that all the evidence is not subject to the power of evidence.

The frequent occurrence of back and forth case files between investigators - public prosecutors-can be understood because the case file is often still not perfect. Attorney $\mathrm{Pu}$ considers the file is not yet eligible formal or material to proceed to the prosecution stage. It often happens because of 2 things, firstly because of the limitations of the ability and quality of investigators or PPNS in conducting investigations and making dockets; secondly, because in reality, it is the auxiliary investigators who conduct more frequent investigations and filings. In general, it can be described as the position of PPNS, Police Investigators, and Public Prosecutors in carrying out the task of investigation are as follows:

a. PPNS position is under the "coordination" and "supervision" of police investigators.

b. For investigation, police investigators provide instructions to PPNS and provide necessary investigative assistance (Article 107 paragraph 1 KUHAP).

c. Certain PPNS must report to the Police investigators about a criminal act being investigated (it does not need to be reported to the JPU). From the investigation by PPNS, there is strong evidence to submit the case to the JPU (Article 107 paragraph 2 KUHAP).

d. If PPNS has finished the investigation, the results must be submitted to the Public Prosecutor, but the way of submission is done PPNS "through police investigators" (Article 107 paragraph (3) KUHAP.

e. If PPNS stops the investigation that has previously been reported to the Police investigators, it must be notified to the Police investigators and JPU Article 109 paragraph 3).

Before the Police investigator continues the PPNS investigation results to the JPU, the Police investigator has the right and authority to examine and examine the case file. If it is considered incomplete, then the Police investigator has the right to give instructions to PPNS to conduct additional investigations (Article 107 paragraph 1 KUHAP).

The position of PPNS under the coordination and supervision of police investigators that has been running for a long time since the enactment of KUHAP turned out to have fatal implications. In reality, PPNS even becomes inferior, not confident in carrying out its duties and authorities, and in such a system that runs for a long time finally dwarfs the role, existence, mental and capability of PPNS. The part of PPNS in the criminal justice system is still castrated within the KUHAP itself. Each Ministry in the government that has PPNS to enforce the law and control the implementation of Administrative Penal Law in authority still 
has not empowered its human resources and is increasingly shackled by a system that weakens them systematically.

In everyday reality, in the agencies that have PPNS, it turns out that the position of PPNS is often held by officials who hold strategic structural roles in the organization of the agency so that they more often "ignore" their position as investigators, they prefer routine work as structural positions, as a result of the position and predicate as PPNS only on paper with the ability of investigation is very concerning.

Police investigators have the right and authority to examine and examine the files of the results of investigations made by PPNS and then provide instructions to conduct additional analyses to PPNS. Isn't that something that extends the bureaucratic chain of handling cases? Therefore, it is a portion of JPU's authority in pre-prosecution. For example, there is a topic that has been back and forth between PPNS and police investigators. The Police investigators forwarded to the JPU. It turns out that JPU still considers the file is not yet eligible to continue at the prosecution stage, so it must be returned to the Police investigators and PPNS. This is undoubtedly very rambling and contrary to the principle of handling cases/judiciary that is simple, fast and cheap.

Indeed reviewed in terms of management, law enforcement's implementation involving several organization agencies in the implementation process under their respective functions and authorities requires modification of patterns and clarification. But in improving, pattern modification and clarification of roles and references should not give rise to centrist agencies. Each apparatus agency must be a subsystem that supports the total system of law enforcement processes in a comprehensive unity. In fact, from now on, it must be thought of the coaching steps that lead to the institutionalization of law enforcement power tools in a pattern of law enforcement centre, which is an agency that gathers them in an integrated law enforcement system in a "centre of law enforcement". There was a process of law enforcement in the centre, ranging from the investigation, prosecution, and trial.

\section{Conclusion}

Departing from the description above, the position and role of PPNS should be strengthened and empowered. They have indeed been given special authority by KUHAP, in Article 6 paragraph (2) letter b, namely civil servants who have the function and control as investigators. The rule they have based on the provisions of the particular criminal law has established the granting of investigative authority in one of the articles. However, the position and role of PPNS in the criminal justice system are still castrated in the KUHAP itself.

Because of the above, it may be time and should the position of PPNS aligned its dignity, existence and ability with police investigators so that our criminal justice system can better anticipate the challenges of the development of the times and criminality that is increasingly sophisticated and complex so that various laws that are Administrative Penal Law that today more and more, can be enforced so that it is not only a paper tiger only. In terms of the position and rank of PPNS stipulated in the Government Regulation, aligned and balanced with police investigators, public prosecutors, and judges of the general judiciary. Should the position of PPNS as an investigator also get a functional differentiation equivalent to the Police investigators in KUHAP, it's just that the authority of the investigation owned PPNS only limited as long as it relates to the criminal acts stipulated in the special criminal law. Then in terms of quantity and quality of investigation capabilities and the manufacture of dockets must continuously be improved so that each Ministry has an adequate PPNS to 
enforce the applicable law in the scope of its authority, especially the law that has illegal material.

The position of PPNS, which is often held by officials who hold strategic structural places, can still be understood but as a step of renewal and improvement in the future should be in every agency that has PPNS formed a particular unit consisting of PPNS which is a functional position and the PPNS has a unique job description only to carry out the functions of PPNS as law enforcement in their field. Furthermore, the quality and quantity of PPNS must be improved, including its facilities and infrastructure and an adequate budget to support their tasks' performance and implementation.

\section{References}

[1] Ardita, Mikho. 2020. "Tanggung Jawab Negara Terhadap Jaminan Kesehatan Dalam Perspektif Hak Asasi Manusia." Jurnal HAM 11(2): 319-33.

[2] Ibnu Suka, Gunarto, U. M. (2018). Peran dan Tanggung Jawab Polri Sebagai Penegak Hukum dalam Melaksanakan Restorative Justive untuk Keadilan dan Kemanfaatan Masyarakat. Jurnal Hukum Khaira Ummah, 13(1), 111-118.

[3] Rendra, G. (2019). Kewenangan Penuntut Umum Dalam Penyidikan Perkara Pencegahan Pemberantasan Perusakan Hutan (P3H). Jurnal Yuridis, 6(2), 157. https://doi.org/10.35586/jyur.v6i2.1076

[4] Supriyanto, E. E. (2021). Konsep Pembangunan dan Pengembangan Ekowisata. In Pengantar Manajemen Potensi Desa: Aku Yakin Desaku Punya Sejuta Potensi (Vol. 1, Issue 1 , pp. 116-129). http://dx.doi.org/10.1016/j.cirp.2016.06.001\%0Ahttp://dx.doi.org/10.1016/j.powtec.20 16.12.055\%0Ahttps://doi.org/10.1016/j.ijfatigue.2019.02.006\%0Ahttps://doi.org/10.10 16/j.matlet.2019.04.024\%0Ahttps://doi.org/10.1016/j.matlet.2019.127252\%0Ahttp://dx .doi.o

[5] Supriyanto, E. E. (2021). Politik Kebijakan Ketahanan Pangan Indonesia Pasca Pandemi Covid-19. In Pertanian Dalam Ketahanan Pangan Selama dan Sesudah Covid-19 (Vol. 1, Issue 1, pp. 33-43). Penerbit Yayasan Guna Widya Paramesthi. 